\title{
Environmental Benefits of the Integrated Alternative Technologies of the Portland Cement Production: A Case Study in Thailand
}

\author{
Parinya Khongprom ${ }^{1, a}$ and Unchalee Suwanmanee ${ }^{2, b, *}$ \\ 1 Department of Industrial Chemistry, Faculty of Applied Science, King Mongkut's University of \\ Technology North Bangkok, Bangkok 10800, Thailand \\ 2 Department of Chemical Engineering, Faculty of Engineering, Srinakharinwirot University, \\ Nakhon-Nayok 12110, Thailand \\ E-mail: apariny.k@sci.kmutnb.ac.th, bunchalee@g.swu.ac.th (Corresponding author)
}

\begin{abstract}
Under the 2012-2050, the International Energy Agency (IEA) and the World Business Council for Sustainable Development (WBCSD) have developed a roadmap for the reduction of energy and carbon intensities in cement production. The aim of this research is to study and evaluate the energy consumption (EN), global warming potential (GWP) impact, and economic assessment of Portland cement production. It was found that the total EN and GWP of conventional process were 3.29 GJ per ton of Portland cement and 0.76 ton $\mathrm{CO}_{2}$ equivalent per ton of Portland cement, respectively. The total cost was $1,346 \mathrm{THB}$ per ton of Portland cement. The largest contribution was from fossil fuels used and the limestone calcination in clinker production which produced the total EN of $83.63 \%$ and the total GWP of $91.36 \%$, and the total cost of $63 \%$. In addition, the production of Portland cement was environmentally improved by using low carbon fuels, increasing of alternative fuels to fossil fuels ratio, and increasing of pozzolan to cement ratio. The results showed that all improvements significantly reduce the total EN, GWP, and the total cost. When the using of low carbon fuels, the increasing of alternative fuels to fossil fuels ratio, and the increasing of pozzolan to cement ratio, the EN, GWP, and the total cost were decreased by $1.68 \%, 18.33 \%$, and $4.39 \%$ of the total $\mathrm{EN}$ and by $25.35 \%, 3.06 \%$, and $10.45 \%$ of the total GWP, and by $4.6 \%, 4.12 \%$, and $10.64 \%$ of the total cost, respectively.
\end{abstract}

Keywords: Energy consumption, environmental impacts, global warming potential, life cycle assessment, Portland cement.

ENGINEERING JOURNAL Volume 21 Issue 7

Received 20 February 2017

Accepted 24 April 2017

Published 29 December 2017

Online at http://www.engj.org/

DOI:10.4186/ej.2017.21.7.15 


\section{Introduction}

The energy crisis and the environmental problems, such as climate change, have been increasing because of the growth of industry and economy. Construction industry is an important contributor to global greenhouse gas (GHG) emissions (11.8\% of total GHG emission of all the industrial and energy sources) [1]. Certainly, cement is an essential material for the construction sector because of its many advantages including natural abundance, relatively low cost, appropriate mechanical properties, and etc. [2-4]. The primary raw materials for cement producing include limestone, shale, and clay, which are accounted over $90 \%$ by weight [5]. The cement production process consists of extraction of raw materials at quarry and mine sites, preparation of raw materials, crushing and burning of raw materials to form clinker, grinding and blending of cement, and transportation. The cement production is high energy and carbon intensities [2], [6-8]. The cement production requires enormous heat for kilns generation resulting in an abundant energy consumption. Moreover, there are two main sources of $\mathrm{CO}_{2}$ releasing from kilns making, which are the combustion of fossil fuels and the calcination of limestone in the cement kilns. This calcination reaction is a decomposition of $\mathrm{CaCO}_{3}$ to form $\mathrm{CaO}$ and $\mathrm{CO}_{2}$ [9-11]. Other gaseous emissions to air from cement production include sulfur dioxide $\left(\mathrm{SO}_{2}\right)$, nitrous oxide (NOx), and methane $\left(\mathrm{CH}_{4}\right)$, etc. Global strategic management reported that the average annual production and consumption of cement has been steadily increasing from 2,283 million tons per year in 2005 to 2,836 million tons per year in 2010 , or about $4.7 \%$ globally [12]. This industrial sector contributes to about $5-7 \%$ of total $\mathrm{CO}_{2}$ emissions worldwide [13]. These figures are corresponding to an average world carbon emission of cement production of $0.81 \mathrm{~kg} \mathrm{CO}_{2}$ per $\mathrm{kg}$ [2]. Therefore, the International Energy Agency (IEA) and the World Business Council for Sustainable Development (WBCSD) have developed a roadmap for the reduction of energy and carbon intensities in cement production. This roadmap aims to create awareness about the problems of energy consumption and $\mathrm{CO}_{2}$ emission. The plan includes the usage of low carbon fuels, the decreasing of clinker to cement ratio into $71 \%$, the increasing of alternative fuels to fossil fuels ratio into $37 \%$, and the usage of carbon capture and storage (CCS). These targets are aimed to reach in year 2050.

Life cycle assessment (LCA) methodology is an effective tool for understanding and improving the environmental impacts of process and product. Several LCA studies have been conducted to assess the performance and environmental impacts of the various cement manufacturing. Huntzinger and Eatmon [14] studied and examined the environmental life cycle of four cement products, which are the traditional process, blended cement with natural pozzolan of $25 \%$, carbon sequestration in cement kiln dust (CKD), and recycling CKD. Their results indicated that blended cements showed the greatest energy and GHG saving about $20 \%$. The improvement of using the CKD leads to $5 \%$ lower environmental impacts than the traditional process. The recycling of CKD exhibited the insignificant environmental saving over the traditional process. Feiz et al. [15] examined the global warming potential (GWP) impact of five different clinker substitutions at rate of $0 \%$ (conventional process), 10\%, 53\%, 60, and $75 \%$ in cement manufacturing. Their results indicated that the clinker substitution rate significantly effects on the environmental impact. The total GWP impact values of cement manufacturing were decreased between $8.35 \%$ and $69 \%$ with increasing of the clinker substitution rate.

In Thailand, the cement production continuously increases every year. The average domestic annual production of cement in 2014 was 35.85 million tons which corresponded to 0.46 tons of cement consumption per capita [16]. The high amount of GHG emissions from cement industrial sector of 12.7 million tons $\mathrm{CO}_{2}$ equivalent or $79.3 \%$ of the total GHG emissions of all industrial sectors in 2000 was observed by Office of Natural Resources and Environmental Policy and Planning. However, there is still a lack of investigation on the environmental impacts of Portland cement production and additional alternative technology on cement production process in Thailand. In this study, the impacts of energy consumption (EN), global warming potential (GWP), and economic assessment of Portland cement productions in Thailand were studied using Life Cycle Assessment (LCA) methodology. Life cycle inventory (LCI) and life cycle impact assessment (LCIA) from cradle to gate of Portland cement production were assessed. The options for the environmental improving of the Portland cement production were also proposed.

\section{Material and Methods}

LCA is an important tool to evaluate and quantify the potential of environmental burden of product's life cycle. LCA is used to quantify the environmental impacts in accordance with the ISO standard [17-18]. Four main parts of the LCA studied in this work were the selection of goal and scope, the determination and 
evaluation of inventory, the assessment of environmental impacts according to inventory results, and the interpretation of the results.

\subsection{LCA Goal and System Boundary}

The functional unit used in this study is defined as 1 ton of Portland cement. Several processing steps are combined to clarify the inventory results. Figure 1 shows the scope of conventional Portland cement production. The raw materials (limestone and shale) obtained from quarry and mine sites were crushed and milled to form fine powder. The powder was then burned to form clinker or kiln products by burning process. The clinker was grounded and then was mixed with gypsum and clinker substitutions to produce cement product. Transportations of raw materials, chemicals, and fuels to cement manufacturing were considered. The improved options by adjusting raw materials and fuels were proposed. The changing of production systems leads to the changing of the LCI.

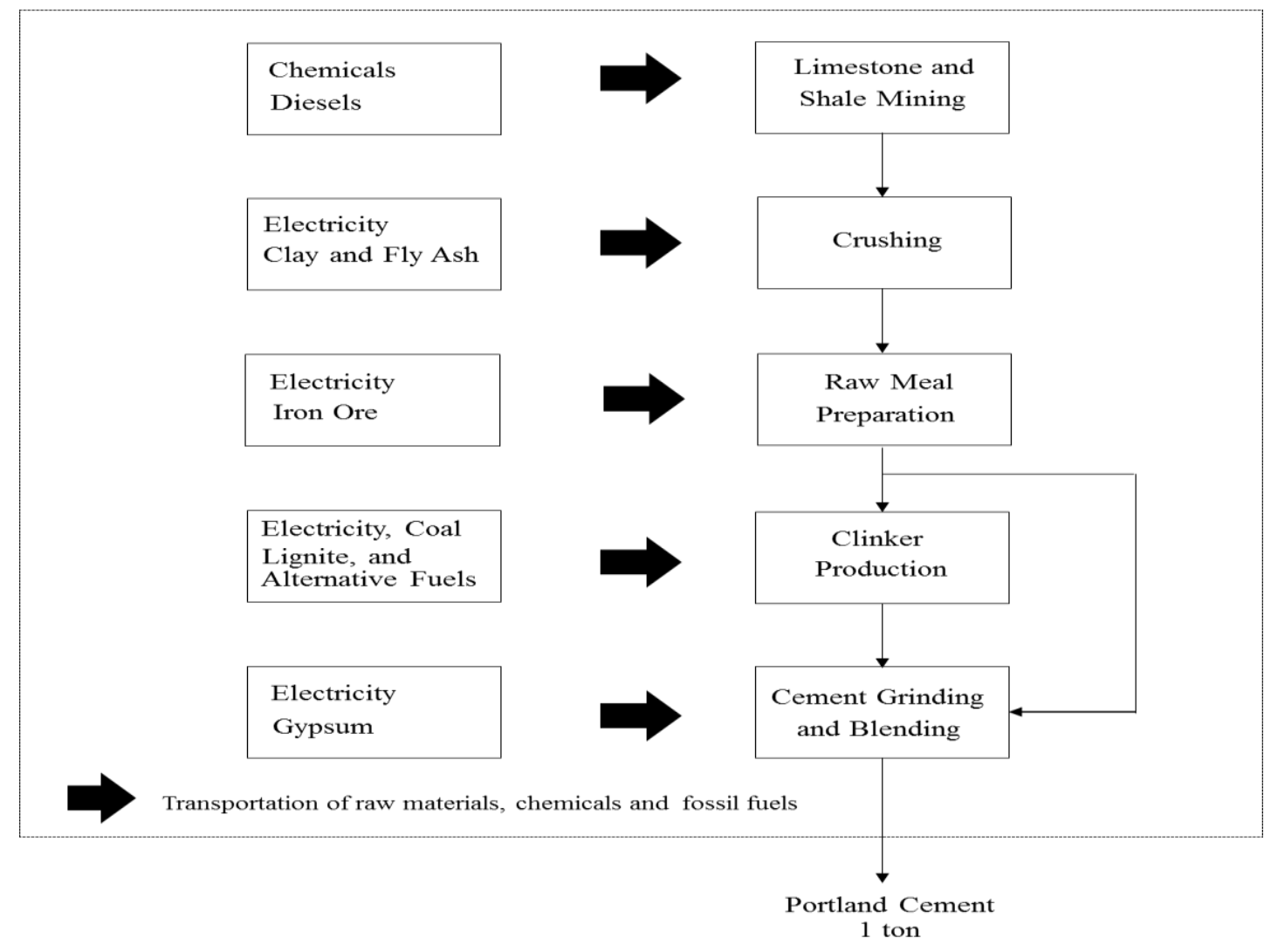

Fig. 1. The scope of conventional Portland cement production.

\subsection{Data Source, Assumption, And Limitation}

Primary data on cement production was collected from cement manufacturing in Thailand within 2012. The secondary data used in this study was taken from literature, Ecoinvent 2.0 database (2007) [19], and IPCC (2006) [20]. The electricity used was based on Thai National Life Cycle Inventory Database [21] and energy report [22]. The data of natural gas was adopted from Varabuntoonvit (2008) [23].

\subsection{Energy Consumption (EN)}

The energy was consumed in six steps of Portland cement production: (i) the use of fossil fuels and chemicals consumed in the quarry sites of mine manufacturing; (ii) the use of electricity, clay and fly ash in the crushing process; (iii) the use of electricity and iron ore in the raw materials preparation step; (iv) the use of electricity, fossils and alternative fuels in the calcination process of clinker; (v) the use of electricity, gypsum and raw 
materials preparation in the cement grinding and blending of cement manufacturing; and (vi) the use of fuels for the transportation stage. The EN of Portland cement can be calculated by using Eq. (1).

$$
\mathrm{EN}_{\text {Cement }}=\sum_{\mathrm{i}=1}^{\mathrm{k}} \sum_{j=1}^{\mathrm{n}}\left(\mathrm{Q}_{j} \times \mathrm{EC}_{\mathrm{j}}\right)_{\mathrm{i}}
$$

where, the subscript i signifies quarry sites of mine manufacturing, crushing, raw materials preparation, clinker process, cement grinding and blending, and transportation, the subscript $\mathrm{j}$ signifies raw materials, chemicals, fossil fuels, and electricity used in the process, $\mathrm{EN}_{\text {Cement }}$ is the energy consumption in GJ per 1 ton of Portland cement, $Q_{j}$ is the quantity of materials and energy used in step i per 1 ton of Portland cement; $E_{j}$ is the net calorific value of materials and energy sources in MJ (see Table 1).

The calculation of EN for the life cycle Portland cement production from raw materials and chemicals, fossil fuels, and electricity can be calculated by using Eq. (2).

$$
\mathrm{EN}_{\text {Cement }}=\mathrm{EN}_{\text {Raw materials and chemicals }}+\mathrm{EN}_{\text {Fossil fuels }}+\mathrm{EN}_{\text {Electricity }}
$$

where, $\mathrm{EN}_{\text {Raw materials and chemicals }}$ is the $\mathrm{EN}$ from the input of raw materials and chemicals, $\mathrm{EN}_{\text {Fossul fuels }}$ is the $\mathrm{EN}$ from applied fossil fuels, and $\mathrm{EN}_{\text {Electricity }}$ is the EN from applied electricity.

\subsection{Global Warming Potential (GWP) Impact}

The most influential parameter from cement production is $\mathrm{CO}_{2}$ emission which is according to the Intergovernmental Panel on Climate Change (IPCC). $\mathrm{CO}_{2}$ emission is essential to be reduced because it is related to climate change problem [24]. The GWP impact was assessed based on the global warming potentials (GWP) in 100 years time frame according to the IPCC (2007) [25]. The GWP impact based on the six steps of Portland cement production was calculated by using Eq. (3).

$$
\mathrm{GWP}_{\text {Cement }}=\sum_{i=1}^{k} \sum_{j=1}^{n}\left(G_{j} \times G_{j} P_{j}\right)_{i}
$$

where, the subscript $i$ denotes quarry sites of mine manufacturing, crushing, raw materials preparation, clinker process, cement grinding and blending, and transportation, the subscript $\mathrm{j}$ represents the greenhouse gases including $\mathrm{CO}_{2}, \mathrm{~N}_{2} \mathrm{O}, \mathrm{CH}_{4}$ and $\mathrm{SF}_{6}, \mathrm{GWP}_{\text {Cement }}$ is the GWP in $\mathrm{kg}$ or tons of $\mathrm{CO}_{2}$ equivalent per 1 ton of Portland cement, $\mathrm{GHG}_{j}$ is the amounts of greenhouse gases $\mathrm{j}$ from the use of raw materials, chemicals, fossil fuels, and electricity (see Table 1) in the process $i, G_{W P}$ denotes the relative GWP of greenhouse gases $j$ based on 100 years time frame from the IPCC (2007) [25] which are 1, 298, 25 and 22,800 for $\mathrm{CO}_{2}, \mathrm{~N}_{2} \mathrm{O}$, $\mathrm{CH}_{4}$ and $\mathrm{SF}_{6}$, respectively.

The calculation of GWP for the life cycle Portland cement production from raw materials and chemicals, calcination of $\mathrm{CaCO}_{3}$, combustion of fossil fuels, and electricity can be calculated by using Eq. (4).

$$
\begin{gathered}
\mathrm{GWP}_{\text {Cement }}=\mathrm{GWP}_{\text {Raw materials and chemicals }}+{ }^{\mathrm{GWP}} \text { Electricity } \\
+ \text { GWP Calcination and combustion }
\end{gathered}
$$

where GWP Raw materials and chemicals is the GWP from the input of raw materials and chemicals, GWP Electricity is the GWP from applied electricity, and GWP Calcination and combustion is the GWP from calcination and combustion reactions.

\subsection{Economic Assessment}

The total cost of Portland cement production and additional alternative technology on cement production were studied. The total cost of all scenario studied were calculated from the summation of raw materials and chemicals, electricity, and fuels used in each step which can be calculated by using Eq. (5). 


$$
C_{\text {Cement }}=\sum_{i=1}^{k} \sum_{j=1}^{n}\left(Q_{j} \times C_{j}\right)_{i}
$$

where, the subscript i signifies quarry sites of mine manufacturing, crushing, raw materials preparation, clinker process, cement grinding and blending, and transportation. The subscript $j$ signifies raw materials and chemicals, fossil fuels, and electricity used in the process, $\mathrm{C}_{\text {Cement }}$ is the total cost in THB per 1 ton of Portland cement, $Q_{j}$ is the quantity of materials and energy used per 1 ton of Portland cement; $C_{j}$ is the cost of materials and energy sources: $C_{\text {Limestone and shale }}$ is 82 THB per ton [26], $C_{\text {Iron }}$ is 28,426 THB per ton [27], $C_{\text {Gypsum }}$ is 31 THB per ton [27], $\mathrm{C}_{\text {Pozzolan }}$ is $20 \mathrm{THB}$ per ton [28], $\mathrm{C}_{\text {Explosive materials and ammonium nitrate }}$ is $38 \mathrm{THB}$ per ton [29], $\mathrm{C}_{\text {Coal }}$ and lignite is 4,925 THB per ton [26], $\mathrm{C}_{\text {Diesel }}$ is $19,528 \mathrm{THB}$ per ton [30], $\mathrm{C}_{\text {Natural gas }}$ is $12,811 \mathrm{THB}$ per ton [30], and $\mathrm{C}_{\text {Electricity }}$ is $3.98 \mathrm{THB}$ per $\mathrm{kWh}$ [31].

The calculation of the total cost for the life cycle Portland cement production from raw materials and chemicals, fossil fuels, and electricity can be calculated by using Eq. (6).

$$
\mathrm{C}_{\text {Cement }}=\mathrm{C}_{\text {Raw materials and chemicals }}+\mathrm{C}_{\text {Fossil fuels }}+\mathrm{C}_{\text {Electricity }}
$$

where, $\mathrm{C}_{\text {Raw materials and chemicals }}$ is the cost of the input of raw materials and chemicals, $\mathrm{C}_{\text {Fossul fuels }}$ is the cost of applied fossil fuels, and $\mathrm{C}_{\text {Electricity }}$ is the cost of applied electricity.

\section{Results}

\subsection{Inventory Results of Conventional Portland Cement Production (Conventional Case)}

The production of 1 ton of conventional Portland cement (see Fig. 1.) requires four major raw materials including 1.086 tons of limestone $(\mathrm{CaO}), 0.132$ ton of shale $(\mathrm{MgO}), 0.037$ ton of clay $\left(\mathrm{Al}_{2} \mathrm{O}_{3}\right), 0.156$ ton of fly ash $\left(\mathrm{SiO}_{2}\right)$, and 0.0017 ton of iron ore $\left(\mathrm{Fe}_{2} \mathrm{O}_{3}\right)$. The LCI of limestone production and shale mining were collected from primary data. The production of 1 ton of limestone or shale requires $0.22 \mathrm{~kg}$ of ammonium nitrate, $0.024 \mathrm{~kg}$ of explosive materials, and $0.52 \mathrm{~kg}$ of diesel. While, the production data of ammonium nitrate, explosive materials, clay, and iron ore were available from Ecoinvent 2.0 database [19]. Fly ash from combustion of solid waste, which contains significant quantities of metal compounds, was taken from power generation plant in Prachinburi and Rayong provinces, Thailand. In addition, 1 ton of Portland cement consists of $81 \%$ of clinker and $19 \%$ of clinker substitution (gypsum $\left(\mathrm{CaSO}_{4}\right) 15 \%$ and limestone $4 \%$ ).

The overall energy used for Portland cement production can be classified into 2 parts including the energy used for production and for transportation. For 1 ton of Portland cement production, the majority of energy sources are electricity $(89.52 \mathrm{kWh})$, coal $(0.089 \mathrm{ton})$, lignite $(0.061 \mathrm{ton})$, and alternative fuels or waste fuels (0.016 ton). The inventory of electricity used was investigated based on Thai National Life Cycle Inventory Database in 2009 [21]. The production data of coal and lignite mining was available from Ecoinvent 2.0 database [19].

The fuel used for transportation was 0.0032 ton of diesel by fully loaded 40 tons-truck and 0.0005 ton of heavy oil by transoceanic freight ship. This investigation was based on Ecoinvent 2.0 database [19]. The raw materials were transported both on land and on sea. This study presumed the average distance of $20 \mathrm{~km}$ road transportation for limestone, shale, and clay delivery from mining to cement manufacturing site. The average distance to transport fly ash from power plants to cement manufacturing site was $186.5 \mathrm{~km}$. The distance to convey gypsum from mining site in Nakornsawan province to cement plant was estimated about $175 \mathrm{~km}$ [33]. Iron ore was firstly transported from the Far East Asian to Thailand by shipment and then was delivered to the cement factory by a fully loaded 40 tons-truck, and distances for iron ore transportation were estimated to be $4,714 \mathrm{~km}$ on sea and $201 \mathrm{~km}$ on land. The delivery distance from mining site of lignite in the North of Thailand to the cement factory was $798 \mathrm{~km}$. The average delivery distance of alternative fuels from Samutprakarn and Rayong provinces to cement manufacturing was $213.5 \mathrm{~km}$. Coal was delivered from the South S.E. Asian to Thailand by shipment with the distance of $2,143 \mathrm{~km}$, and then was conveyed by a fully loaded 40 tons-truck to the cement factory with the distance of $201 \mathrm{~km}$. 
Table 2 exhibits the emissions inventory of conventional Portland cement production. The $\mathrm{CO}_{2}$ emission from clinker process was $699.697 \mathrm{~kg}$, which is $90 \%$ of total amount of $\mathrm{CO}_{2}$ emission or 0.86 ton per ton of clinker. This result was similar to the observation of previous works [2], [13], [34-36]. They found that the total amount of $\mathrm{CO}_{2}$ emission per ton of clinker was in the range of $0.8-1.2$ tons. Moreover, the amounts of $\mathrm{CO}_{2}$ emission obtained from the raw materials decarbonation and the consumption of fossil fuels were $55.09 \%$ and $44.91 \%$ of total $\mathrm{CO}_{2}$ emission during the clinker production, respectively. This result was also consistent with previous studies [5], [34]. They reported that about $60 \%$ of $\mathrm{CO}_{2}$ emission from cement production mainly comes from calcination of limestone and the remaining ratios produces from combustion of fossil fuels used to achieve the high temperature required for calcination reaction.

Table 1. The net calorific value and GHG emissions of materials and energy sources.

\begin{tabular}{|c|c|c|c|c|c|c|c|}
\hline $\begin{array}{c}\text { Raw materials } \\
\text { and } \\
\text { energy sources }\end{array}$ & Unit & $\begin{array}{l}\text { Calorific } \\
\text { value } \\
\text { (MJ/unit) }\end{array}$ & $\begin{array}{c}\mathrm{CO}_{2} \\
\text { (kg/unit) }\end{array}$ & $\begin{array}{c}\mathrm{CH}_{4} \\
\text { (kg/unit) }\end{array}$ & $\begin{array}{c}\mathrm{N}_{2} \mathrm{O} \\
\text { (kg/unit) }\end{array}$ & $\begin{array}{c}\mathrm{SF}_{6} \\
\text { (kg/unit) }\end{array}$ & Reference \\
\hline $\begin{array}{l}\text { Ammonium } \\
\text { nitrate }\end{array}$ & $\mathrm{kg}$ & 59.40 & 0.29694 & 0.00547 & 0.00096 & 0.00 & [19] \\
\hline Clay & $\mathrm{kg}$ & 0.028 & 0.00018 & 0.00 & 0.00 & 0.00 & [19] \\
\hline Coal (production) & $\mathrm{kg}$ & 26.37 & 0.00612 & 0.00 & 0.00 & 0.00 & [19], [22] \\
\hline $\begin{array}{l}\text { Coal (stationary } \\
\text { combustion) }\end{array}$ & $\mathrm{kg}$ & 26.37 & 2.52743 & 0.00026 & 0.00004 & - & {$[21],[22]$} \\
\hline $\begin{array}{l}\text { Diesel } \\
\text { (production) }\end{array}$ & $\mathrm{kg}$ & 43.36 & 0.30500 & 0.00089 & 0.00 & - & [21], [22] \\
\hline $\begin{array}{l}\text { Diesel (mobile } \\
\text { combustion) }\end{array}$ & $\mathrm{kg}$ & 43.36 & 3.21298 & 0.00017 & 0.00005 & - & [20], [22] \\
\hline Electricity & kwh & 5.30 & 0.60600 & 0.00004 & 0.00 & 0.00 & {$[21]$} \\
\hline $\begin{array}{l}\text { Explosive } \\
\text { materials }\end{array}$ & $\mathrm{kg}$ & 31.90 & 2.06870 & 0.00360 & 0.029247 & 0.00 & [19] \\
\hline $\begin{array}{l}\text { Waste } \\
\text { (incineration) }\end{array}$ & $\mathrm{kg}$ & 23.97 & 0.45100 & - & 0.00 & - & {$[20],[32]$} \\
\hline Gypsum & $\mathrm{kg}$ & 0.037 & 0.00022 & 0.00 & 0.00 & 0.00 & [19] \\
\hline Heavy oil & $\mathrm{kg}$ & 46.96 & 0.00021 & 0.00 & 0.00 & 0.00 & [21], [22] \\
\hline $\begin{array}{l}\text { Heavy oil (mobile } \\
\text { combustion) }\end{array}$ & $\mathrm{kg}$ & 46.96 & 3.44217 & 0.00014 & 0.00003 & - & [20], [22] \\
\hline Iron ore & $\mathrm{kg}$ & 0.074 & 0.00073 & 0.00 & 0.00 & 0.00 & [19] \\
\hline $\begin{array}{l}\text { Lignite } \\
\text { (production) }\end{array}$ & $\mathrm{kg}$ & 10.47 & 0.00339 & 0.00 & 0.00 & - & {$[21],[22]$} \\
\hline $\begin{array}{l}\text { Lignite } \\
\text { (combustion) }\end{array}$ & $\mathrm{kg}$ & 10.47 & 1.05747 & 0.00010 & 0.00001 & - & [20], [22] \\
\hline Natural gas & $\mathrm{kg}$ & 54.00 & 0.00002 & 0.00 & 0.00 & - & {$[22],[23]$} \\
\hline
\end{tabular}


Table 2. Emissions inventory of conventional Portland cement production (conventional case).

\begin{tabular}{|c|c|c|c|c|}
\hline \multirow[t]{2}{*}{ Process } & \multicolumn{4}{|c|}{ Emissions (kg) } \\
\hline & $\mathrm{CO}_{2}$ & $\mathrm{CH}_{4}$ & $\mathrm{~N}_{2} \mathrm{O}$ & $\mathrm{SF}_{6}$ \\
\hline $\begin{array}{l}\text { 1. Limestone and shale } \\
\text { mining production }\end{array}$ & 2.35959 & 0.00225 & 0.00114 & 0.00 \\
\hline 2. Crushing production & 0.63925 & 0.00008 & 0.00004 & 0.00 \\
\hline 3. Raw materials preparation & 13.5782 & 0.00082 & 0.00018 & 0.00 \\
\hline 4. Clinker production & 699.697 & 0.03168 & 0.00494 & 0.00 \\
\hline $\begin{array}{l}\text { 5. Cement grinding and } \\
\text { blending }\end{array}$ & 23.8208 & 0.00172 & 0.00047 & 0.00 \\
\hline 6. Transportation & 25.2213 & 0.00352 & 0.00040 & 0.00 \\
\hline
\end{tabular}

\subsection{Inventory Results of Using Low Carbon Fuels (Scenario 1)}

Fuels are classified here into high carbon fuels (solid phase such as coal, lignite, and biomass) and low carbon fuels (gas and liquid phases such as natural gas and oil) according to their carbon content. High carbon fuels generate higher carbon emissions with lower energy content as compared with low carbon fuels. Replacement of high carbon fuels with low carbon fuels might decrease the environmental impacts. The natural gas as low carbon fuel was used instead of the high carbon fuels such as coal and lignite during the production of clinker [2]. As a result, there is the change in inventory results of Portland cement when natural gas is in substitute for coal and lignite. The production of 1 ton of Portland cement in scenario 1 requires three types of energy source including $89.52 \mathrm{kWh}$ of electricity, 0.055 ton of natural gas, and 0.016 ton of alternative fuels. The data of natural gas was taken from the secondary source [23]. The energy requirements during transportation consists of 0.0017 ton of diesel by fully loaded 40 tons-truck, $1.99 \times 10^{-5}$ ton of heavy oil by transoceanic freight ship, and $5.51 \times 10^{-4}$ ton of natural gas by pipeline transportation. The information of pipeline transportation was taken from Ecoinvent 2.0 database [25]. Natural gas was piped from the Gulf of Thailand and then was delivered by a fully loaded 40-tons truck to the cement factory. The estimated distances were 687 and $20 \mathrm{~km}$, respectively. It is assumed that the information on the conversional process was taken from the conventional Portland cement production in previous section. It can be seen that the total amount of $\mathrm{CO}_{2}$ emissions of scenario 1 was clearly decreased by $183.3 \mathrm{~kg} \mathrm{CO}$ or $24.60 \%$ of total $\mathrm{CO}_{2}$ emissions of base case. The reduction amounts of GHG emissions obtained from the production of clinker and transportation stages were $25-99 \%$ and $33-44 \%$ of total GHG emissions, respectively.

\subsection{Inventory Results of the Increasing of Alternative Fuels to Fossil Fuels Ratio (Scenario 2)}

The use of coal and lignite in cement kiln operations generally reveals a major contribution of $\mathrm{CO}_{2}$ emissions about $40 \%$ of total $\mathrm{CO}_{2}$ emission [5]. However, the cement production process potentially be able to use the industrial waste in partial substitute of fossil fuel [2], [5]. The industrial wastes which are commonly used as alternative fuels include solvent and spent oil, plastic waste, sewage sludge, used tyre and etc. [37]. So, cement kilns process presented to be particularly proper for this condition. Then, scenario 2 , where alternative fuels were used in partial substitution of fossil fuels by $20 \%$, is compared with base case, where only $11 \%$ alternative fuels were added to fossil fuels ratio. The production of 1 ton of Portland cement in scenario 2 requires 89.52 $\mathrm{kWh}$ of electricity, 0.078 ton of coal, 0.061 ton of lignite, and 0.028 ton of alternative fuels, 0.0033 ton of diesel transported by fully loaded 40 -tons truck, and $4.40 \times 10^{-4}$ ton of heavy oil delivered by transoceanic freight ship. The major components of raw materials for the production of cement kiln and blended cement were taken from the conventional Portland cement production. This scenario showed the significant reduction and beneficial effect on the $\mathrm{CO}_{2}, \mathrm{CH}_{4}, \mathrm{~N}_{2} \mathrm{O}$ and $\mathrm{SF}_{6}$ emissions. These emissions were decreased by $1.49 \%, 5.40 \%, 1.60 \%$ and $2.80 \%$ of total $\mathrm{CO}_{2}, \mathrm{CH}_{4}, \mathrm{~N}_{2} \mathrm{O}$ and $\mathrm{SF}_{6}$ emissions of base case, respectively. 


\subsection{Inventory Results of Blended Cement (Scenario 3)}

The amount of clinker consumption can be reduced by using supplementary cementitious materials such as fly ash, slag, silica fume, and natural pozzolan [2], [14], [38-39]. In addition, the supplementary cementitious materials could enhance the physical and mechanical properties of the cement. National pozzolan was derived from volcanic glass, zeolitic trass, rice husk ash and diatomaceous earth. The use of pozzolan was considered to substitute the amount of clinker consumption in the range of $10-75 \%$ [6], [14-15]. In scenario 3, it is important to note that the input amounts of raw material and energy used were linearly decreased in proportion to the amount of the additional of natural pozzolan in the clinker substitution rate from 19 to $29 \%$. Based on 1 ton of Portland cement in scenario 3, the unit requires 0.952 ton of limestone, 0.115 ton of shale, 0.032 ton of clay, 0.136 ton of fly ash, and 0.0015 ton of iron ore. The clinker substitutions were 0.05 ton of gypsum, 0.15 ton of limestone, and 0.10 ton of natural pozzolan. The production of pozzolan was supplemented from Ecoinvent 2.0 database [19]. The use of clinker per ton cement was decreased from 0.81 ton to 0.71 ton. The average distance from pozzolan mining sites to cement manufacturing area is $291 \mathrm{~km}$ [33]. The production of 1 ton of Portland cement in scenario 3 requires $89.52 \mathrm{kWh}$ of electricity, 0.078 ton of coal, 0.053 ton of lignite, and 0.014 ton of alternative fuels, 0.0029 ton of diesel for transportation by fully loaded 40 tons-truck, $4.30 \times 10^{-4}$ ton of heavy oil in transportation by transoceanic freight ship, respectively. The total amounts of $\mathrm{CO}_{2}, \mathrm{CH}_{4}, \mathrm{~N}_{2} \mathrm{O}$ and $\mathrm{SF}_{6}$ emissions in scenario 3 were reduced by $10.47 \%, 7.35 \%, 4.81 \%$ and $5.15 \%$ of base case, respectively. It is clearly seen that production of clinker exhibited the highest amount of $\mathrm{CO}_{2}, \mathrm{CH}_{4}$ and $\mathrm{N}_{2} \mathrm{O}$ emissions in the rate of $12-13 \%$ of total emissions.

\section{Discussion}

The considered environmental impacts include the energy consumption and GWP impact associated with Portland cement production in four processes: (i) conventional Portland cement; (ii) using low carbon fuels; (iii) increasing of alternative fuels to fossil fuels ratios; and (iv) blended cement. The results show that the production of clinker exhibits the highest contribution to the total energy used and GWP impact, which are in the range of $81-85 \%$ and $88-92 \%$ of all scenarios studied, respectively (see Figs. 2(a) and 3(a)). This is mainly due to the use of fossil fuels which gave $82-86 \%$ of the total energy for Portland cement one ton (see Fig. 2(b)). This result was similar to the observation of previous works [14], [34]. The decomposition of $\mathrm{CaCO}_{3}$ to form clinker and the combustion of fossil fuels used attributed to approximately $92-93 \%$ of the total GWP impact as shown in Fig. 3(b). Transportation stage and the use of raw materials and chemical slightly affected on the environmental impacts as shown in Figs. 2(b) and 3(b). Similarly, the total cost of cement production was obtained in significant level during the clinker production stages of $62-63 \%$ of the total (see Fig. 4(a)) because the use of fossil fuels, representing $59-61 \% \%$ of the total energy for Portland cement one ton (see Fig. 4(b)).

For base case, the total energy used was 3.29 GJ per ton of Portland cement and the total GWP impact was 0.76 ton $\mathrm{CO}_{2}$ equivalent per ton of Portland cement. The total cost was 1,346 THB per ton of Portland cement. The production of clinker shows the main-contributor to the total energy used by $83.63 \%$. The total GWP impact presented at $91.36 \%$ or about 0.82 ton $\mathrm{CO}_{2}$ equivalent per ton of clinker. The environmental performance of clinker produced in this process is better than that of clinker production in other big countries such as Japan (0.83 ton $\mathrm{CO}_{2}$ equivalent per ton clinker), China (0.90 ton $\mathrm{CO}_{2}$ equivalent per ton clinker), Europe (0.91 ton $\mathrm{CO}_{2}$ equivalent per ton clinker) and USA (0.98 ton $\mathrm{CO}_{2}$ equivalent per ton clinker) [24]. Moreover, the use of fly ash and alternative fuels significantly decreased the total EN by $0.38 \mathrm{GJ}$ and 0.004 GJ or $10.32 \%$ and $0.11 \%$ of the total energy used, respectively. Although the conventional Portland cement production is high environmental impacts, it is possible for further hypothesis improvement to meet the targets of IEA and WBCSD in year 2050. Firstly, the use of low carbon fuels slightly decrease the energy used by $0.055 \mathrm{GJ}$ or $1.68 \%$ as compared with conventional process. This is because energy consumed for natural gas transportation by pipe in scenario 1 is less than energy consumed for coal and lignite transportation by truck and shipment in base case. The process of low carbon fuels usage (scenario 1) showed a significant reduction on the total GWP impact of $25.35 \%$ or 0.194 ton $\mathrm{CO}_{2}$ equivalent and the total cost of $4.6 \%$ or 62 THB. Secondly, by increasing $20 \%$ of the alternative fuels to fossil fuels during the production of clinker in scenario 2, the total energy used was dramatically decreased by $0.60 \mathrm{GJ}$ or $18.33 \%$ of energy used in base case, and the GWP impact was decreased by 0.023 ton $\mathrm{CO}_{2}$ equivalent or $3.06 \%$ of the total impact occurred in base case, and the total cost was decreased by $55.4 \mathrm{THB}$ or $4.12 \%$ compared to base case. Finally, by 
increasing the amount of clinker substitution rate from $19 \%$ to $29 \%$, the significant and beneficial effects on the energy used in cement manufacturing can be reduced by $0.14 \mathrm{GJ}$ or $4.39 \%$, compared to conventional process. Moreover, The GWP impact and the total cost were dramatically decreased by 0.080 ton $\mathrm{CO}_{2}$ equivalent and $143 \mathrm{THB}$ which is accounted for $10.45 \%$ of the total impact of base case and $10.64 \%$ of the total cost of base case, respectively. This is because the amounts of raw materials and energy used to generate kilns were decreased with increasing the amount of natural pozzolan. The pozzolan gave lower cost per ton of materials than limestone and shale by 4 times. Nevertheless, additional technologies for cement production are important strategy to further reduce energy consumption and emissions in the cement production chain.

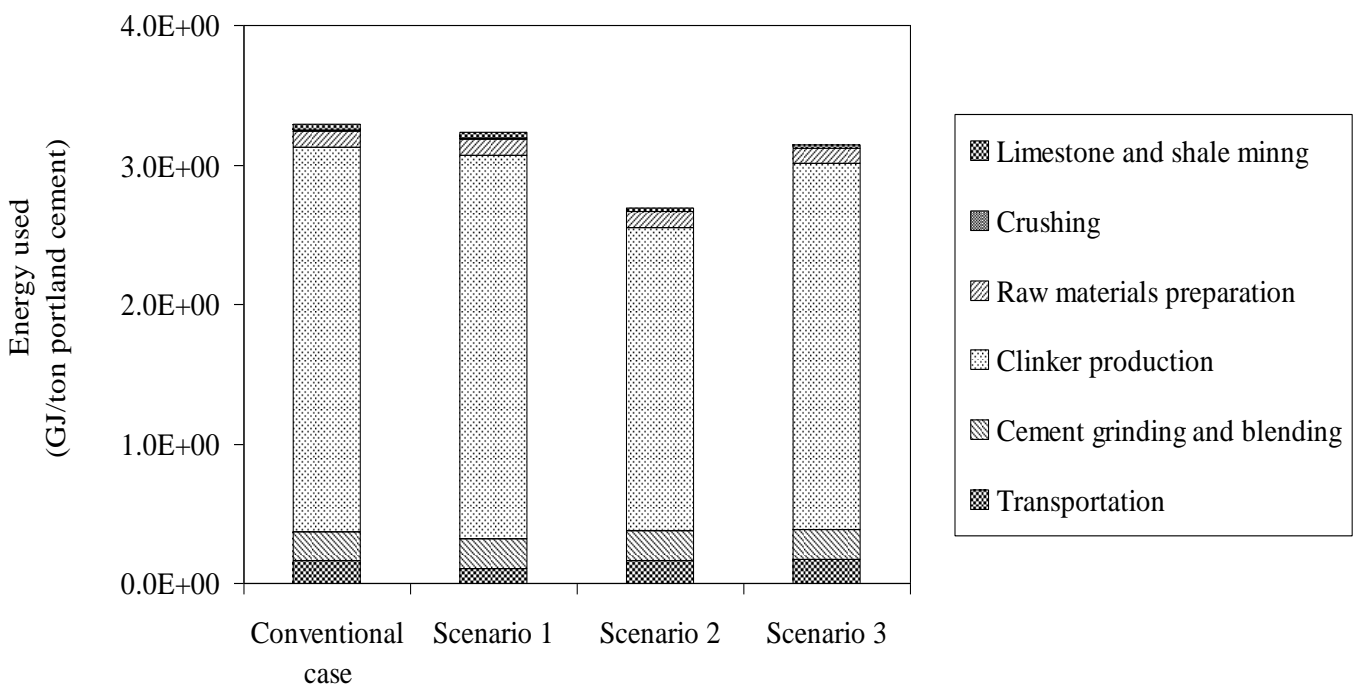

(a)

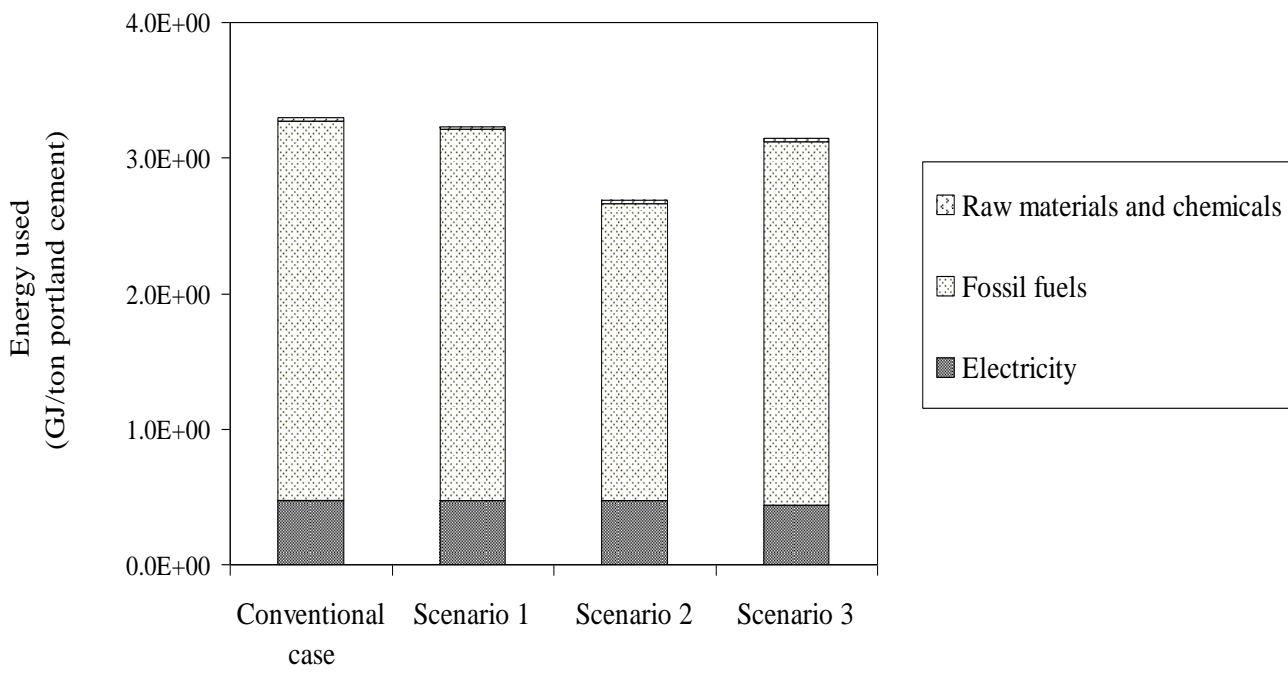

(b)

Fig. 2. Energy consumption of four Portland cement productions: (a) the contribution of each process to Portland cement productions and (b) the contribution of raw materials, chemicals, fossil fuels, and electricity to Portland cement productions. 


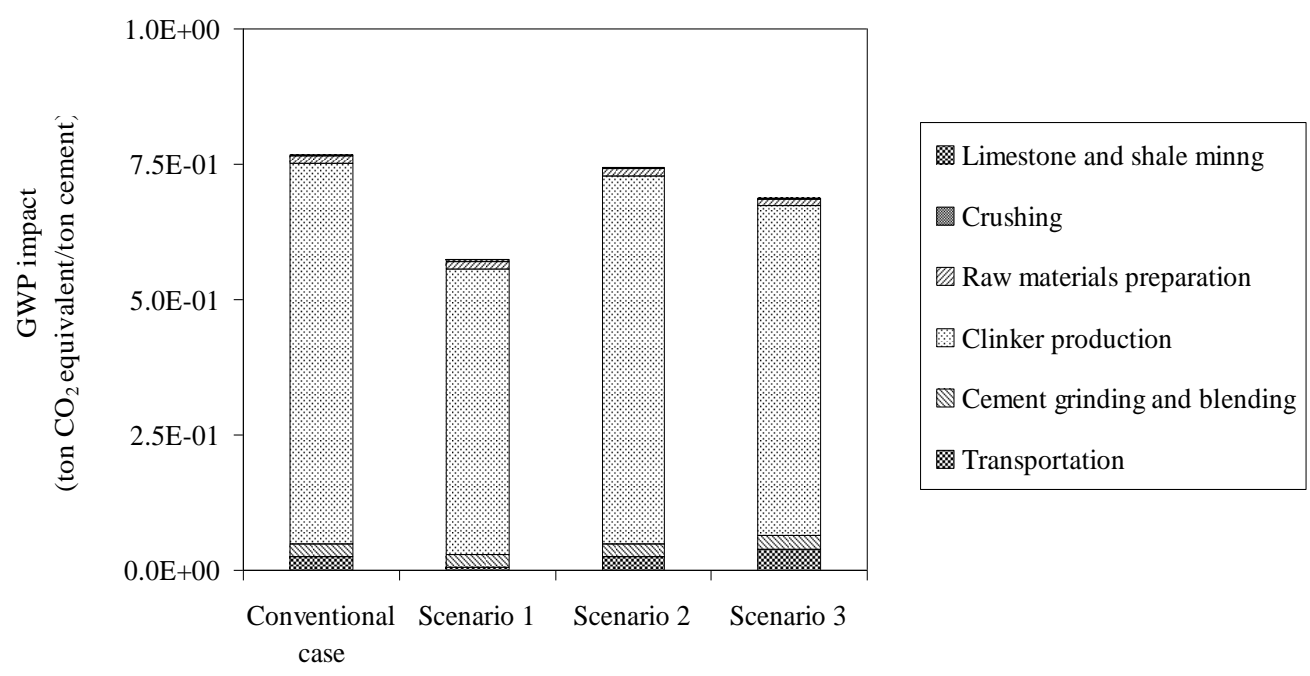

(a)

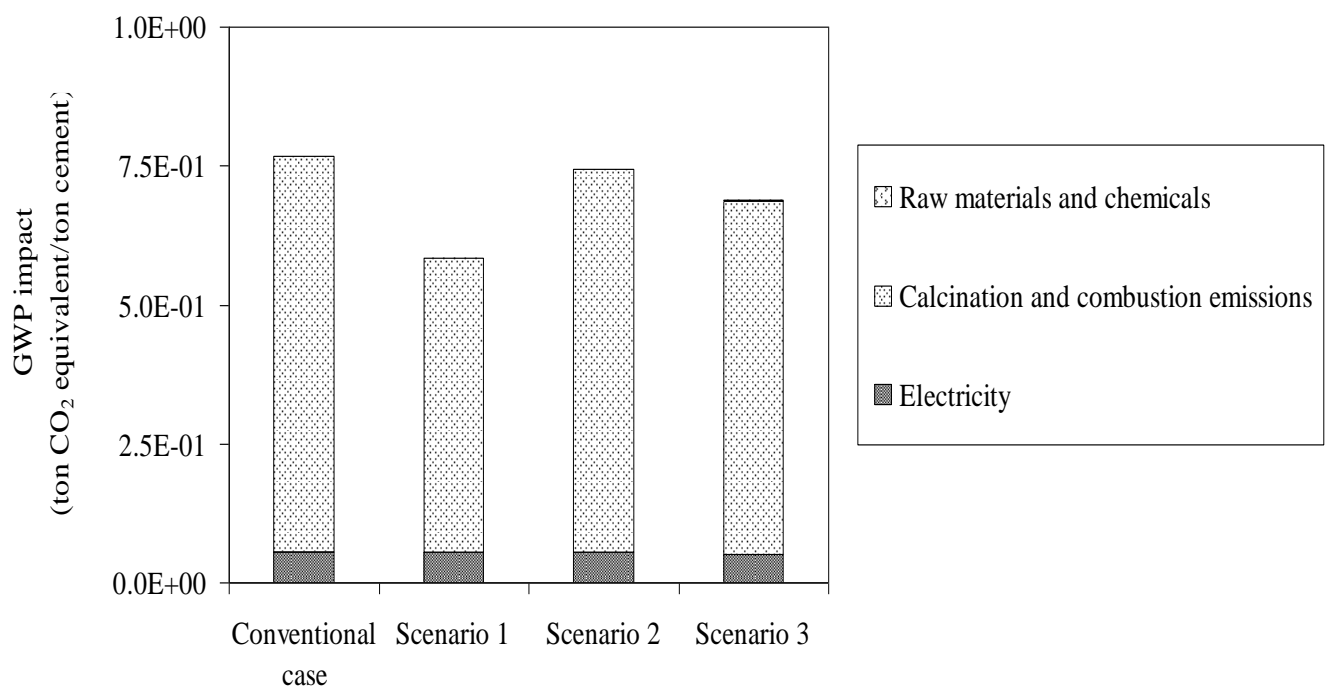

(b)

Fig. 3. The GWP impact of four Portland cement productions: (a) the contribution of each process to Portland cement productions and (b) the contribution of raw materials, chemicals, process and fuels emissions, and electricity to Portland cement productions. 


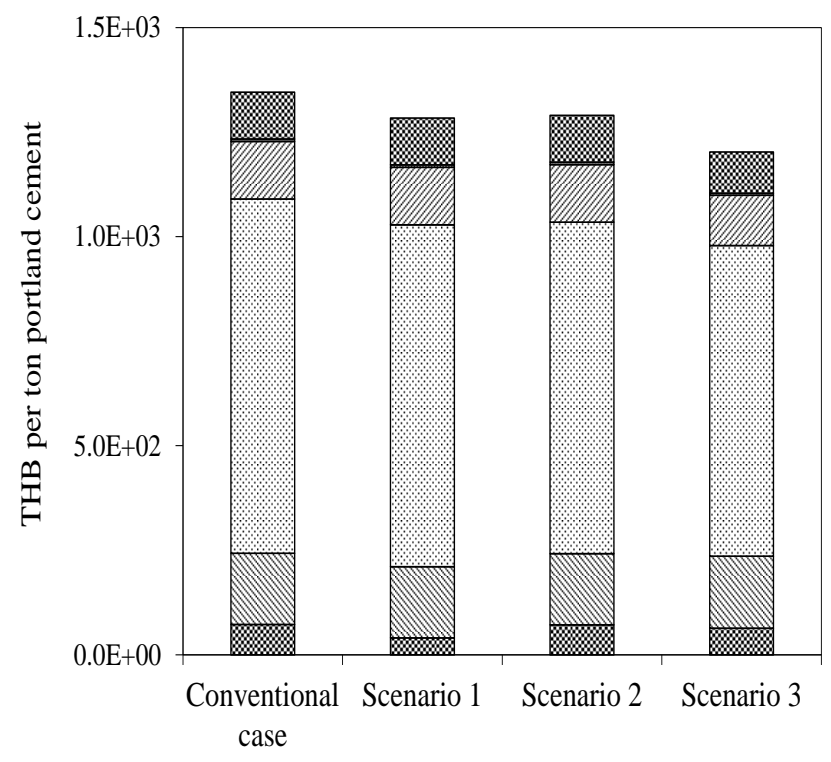

ख Limestone and shale minng

๑Crushing

๑ Raw materials preparation

Clinker production

$\mathbb{}$ Cement grinding and blending

\% Transportation

(a)

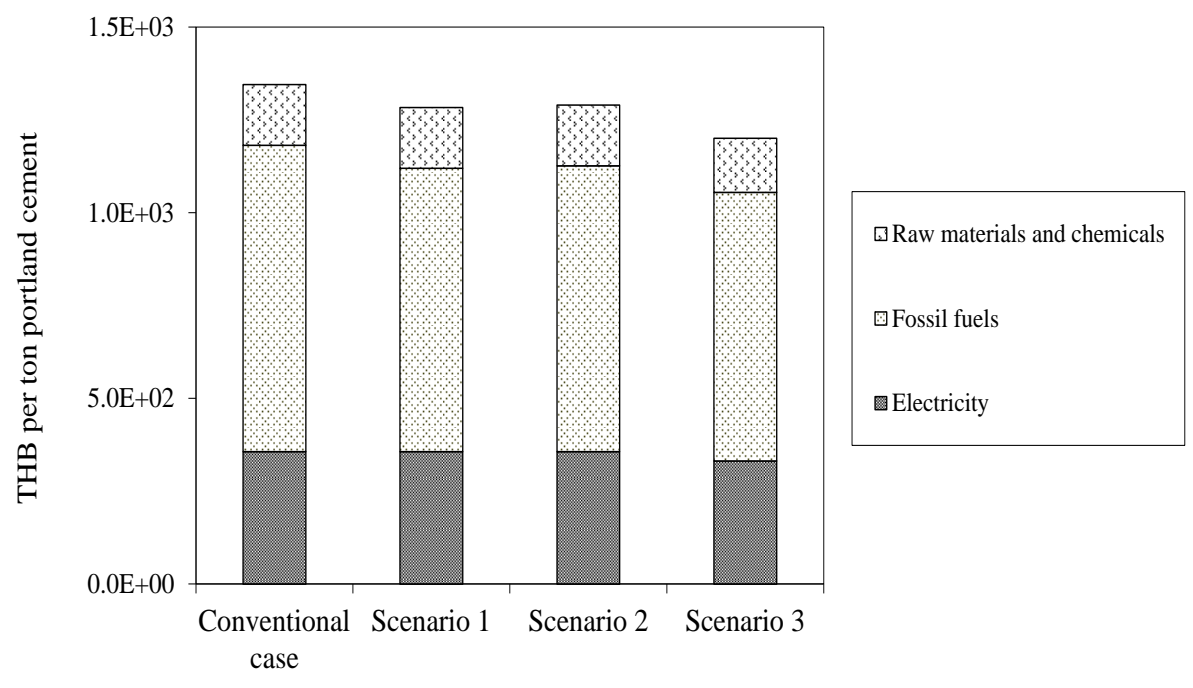

(b)

Fig. 4. The cost of four portland cement productions: (A) the contribution of each process to portland cement productions and (B) the contribution of raw materials, chemicals, process and fuels emissions, and electricity to portland cement productions.

\section{Conclusion}

The environmental impacts in conventional Portland cement exhibit the good performance which are 3.29 GJ per ton Portland cement and 0.76 ton $\mathrm{CO}_{2}$ equivalent per tons Portland cement. The total cost of cement production was 1,346 THB per ton of Portland cement. The variations of raw materials and fuels were significantly contributed to sustainability of cement production. The hypothesis improvement production of Portland cement can be reduced the energy used, the total cost and, especially the most important parameters, the GWP impact in the cement production chain. The energy consumption significantly reduced to $0.60 \mathrm{GJ}$ or $18.33 \%$ by increasing of alternative fuels to fossil fuels ratio. The use of low carbon fuels can be decreased 0.194 ton $\mathrm{CO}_{2}$ equivalent or about $25.35 \%$ of the GWP impact of base case. The using supplementary 
cementitious materials, the total cost was dramatically decreased by $143 \mathrm{THB}$ or $10.64 \%$ of the total cost in base case.

\section{Acknowledgement}

This work has been supported by Department of Chemical Engineering, Faculty of Engineering, Srinakharinwirot University, and Srinakharinwirot University Fund (SWU 175/2556).

\section{References}

[1] Center for Climate and Energy Solutions. (2015). Climate Techbook [Online]. Available: http://www.c2es.org/facts-figures/international-emissions/sector

[2] C. A. Hendriks, E. Worrell, D. Dejager, K. Block, and P. Riemer, "Emission reduction of greenhouse gases from the cement industry," in Greenhouse Gas Control Technologies Conference., UK, 2004, pp. 1-11.

[3] S. Hussain, D. Bhunia, and S. B. Singh, "An experimental investigation of accelerated carbonation on properties of concrete,” Eng. J., vol. 20, no. 2, pp. 29-38, 2016.

[4] S. Thirumurugan and S. Anandan, "Residual strength characteristics of polymer fibre concrete exposed to elevated temperature," Engineering Journal, vol. 19, no. 4, pp. 117-131, 2015.

[5] C. Strazza, A. D. Borghi, M. Gallo, and D. Borghi, "Resource productivity enhancement as means for promoting cleaner production: Analysis of co-incineration in cement plants through a life cycle approach," J. Clean Prod., vol. 19, no. 14, pp. 1615-1621, Sep. 2011.

[6] H. G. Van Oss and A. C. Padovani, "Cement manufacture and environment part I: Chemistry and technology,” J. Indust. Ecol., vol. 6, no. 1, pp. 89-106, Jan. 2002.

[7] L. Reijnders, "The cement industry as a scavenger in industrial ecology and the management of hazardous substances," J. Indust. Ecol., vol. 11, no. 3, pp. 15-25, Jul. 2007.

[8] M. E. Boesch, A. Koehler, and S. Hellweg, "Model for cradle-to-gate life cycle assessment of clinker production,” Environ. Sci. Technol., vol. 43, no. 19, pp. 7578-7583, Oct. 2009.

[9] EPA. (2009). Technical Support Document for Process Emissions from Cement: Proposed Rule for Mandatory Reporting of Greenhouse Gas [Online]. Available: http:/ /www.nepis.epa.gov [Accessed: 28 January 2009].

[10] K. Yang, J. Song, and K. Song, “Assessment of $\mathrm{CO}_{2}$ reduction of alkali-activated concrete," J. Clean. Prod., vol. 39, pp. 265-272, Jan. 2013.

[11] M. Valipour, M. Yekkalar, M. Shekarchi, and S. Panahi, "Environmental assessment of green concrete containing natural zeolite on global warming index in marine environments," J. Clean. Prod., vol. 65, pp. 418-423, Feb. 2014.

[12] Cemex Globolisation. (2008). Global Strategic Management Mini Cases Series [Online]. Avialable: http://www.philippelasserre.net/contenu/Download/Cemex_globalisation.pdf

[13] C. Chen, G. Habert, Y. Bouzidi, and A. Jullien, "Environmental impact of cement production: Detail of the different process and cement plant variability evaluation," J. Clean. Prod., vol. 18, no. 5, pp. 478485, Mar. 2010.

[14] D. N. Huntzinger and T. D. Eatmon, "A life-cycle assessment of Portland cement manufacturing: Comparing the traditional process with alternative technologies," J. Clean. Prod., vol. 17, no. 7, pp. 668675, May 2009.

[15] R. Feiz, J. Ammenberg, L. Baas, M. Eklund, and A. Heigstrand, "Improving the $\mathrm{CO}_{2}$ performance of cement, part I: Utilizing the life-cycle assessment and key performance indicators to assess development within the cement industry," J. Clean. Prod., vol. 98, pp. 272-281, Jul. 2014.

[16] Thai Cement Manufacturers Association. (2014). Supply and Demand, Export of Cement Industry [Online]. Available: http://www.thaicma.or.th/cms/assets/Uploads/tcma2014.pdf [Accessed: 20 September 2014].

[17] Environmental Management-Life Cycle Assessment-Principles and Framework, ISO 14040, International Organization for Standardization, Geneva, Switzerland, 2006.

[18] Environmental Management-Life Cycle Assessment-Requirement and Guidelines, ISO 14044, International Organization for Standardization, Geneva, Switzerland, 2006.

[19] Ecoinvent 2.0 Database, Switzerland, 2007.

[20] IPCC, "Guidelines for national greenhouse gas inventories," Japan, 2006.

[21] MTEC, "Thai National Life Cycle Inventory Database," Thailand, 2009. 
[22] DEDE, "Energy report," Thailand Ministry of Energy, Thailand, 2012.

[23] V. Varabuntoonvit, "Development of life cycle assessment tool with environmental cost accounting based on NETs method," Ph.D. Thesis, Department of Chemical Engineering, KU, Bangkok, Thailand, 2008.

[24] J. Ammenberg, R. Feiz, A. Helgstrand, M. Eklund, and L. Baas. (2011). Industrial Symbiosis for Improving the $\mathrm{CO}_{2}$-Performance of Cement Production [Online]. Avialable: http://liu.diva-portal.org

[25] IPCC, "Climate change 2007: Synthesis report-The fourth assessment report of the IPCC," United Kingdom, 2007.

[26] Chard tilling and Excavating Inc. (2015). 2015 Price List [Online]. Available: http://www.chardtiling.com

[27] Trading Eeconomics. (2016). Trading Economics Commodities [Online]. Available: http://www.tradingeconomics.com/commodities

[28] ClimateTechWiki. (2008). Clinker Substitute (Slag, Natural Pozzolans, Synthetic Pozzolans) [Online]. Available: http://www.climatetechwiki.org/technology/clinker-substitue

[29] Orica Mining Services. (2011). Price List United Kingdom [Online]. Available: https://www.oricaminingservices.com

[30] Bank of Thailand. (2016). EC_RL_008 Price of Certain Manufactured Goods. [Online]. Available: https://www2.bot.or.th

[31] Ministry of Energy. (2016). Electricity Plan and Sale [Online]. Available: https://www.eppo.go.th.

[32] D. Surroop and R. Mohee, "Power generation from refuse derived fuel," in the $2^{\text {nd }}$ International Conference on Environment Engineering and Applications, China, 2011.

[33] Department of Highway. (2013). Distance between Provinces in Thailand [Online]. Available: http://mapserver.doh.go.th

[34] C. J. Koroneos and A. T. Dompros, "Environmental assessment of the cement and concrete life cycle in Greece," Int. J. Environ. Tech. Manage., vol. 10, no. 1, pp. 71-88, 2009.

[35] J.A. Moya, N. Pardo, and A. Mercier. (2010). Energy Efficiency and $\mathrm{CO}_{2}$ Emission Prospective Scenarios for the Cement Industry [Online]. Available: http://www.jrc.ec.europa.eu/

[36] H.G. van Oss and A. C. Padovani, "Cement manufacture and the environment, part II: Environmental challenges and opportunities," J. Indust. Ecol., vol. 7, pp. 93-126, 2003.

[37] A. Rahman, M. G. Rasul, M. M. K. Khan, and S. Sharma, "Industrial waste as alternative fuel in cement industry: Its impact on environment," in Proceedings of the $7^{\text {th }}$ WSEAS International Conference on Energy \& Environment: Recent researches in environmental and geological science, Kos Island, Greece, 2012, pp. 108-114.

[38] T. M. Swe, P. Jongvivatsakul, and W. Pansuk, "Properties of pervious concrete aiming for LEED green building rating system credits," Engineering Journal, vol. 20, no. 2, pp. 61-72, 2016.

[39] R. Wattanapornprom and B. Stimannaithum, "Comparison of properties of fresh and hardened concrete containing finely ground glass powder, fly ash, or silica fume," Engineering Journal, vol. 19, no. 3, pp. 35-47, 2015. 